\title{
Antioxidant properties of species from the Brazilian cerrado by different assays
}

\author{
FARIAS, K.S. ${ }^{1}$; SANTOS, T.S.N. ${ }^{1}$; PAIVA, M.R.A.B. ${ }^{2}$; ALMEIDA, S.M.L. ${ }^{2}$; GUEDES P.T.; VIANNA, A.C.A; \\ FAVARO, S.P. ${ }^{\prime}$; BUENO, N.R. ${ }^{3}$; CASTILHO, R.O. ${ }^{2 *}$ \\ ${ }^{1}$ Curso de Farmácia, Centro de Ciências Biológicas e da Saúde, Universidade Católica Dom Bosco, Avenida \\ Tamandaré, 6000, CEP: 79117-900, Campo Grande-Brasil ${ }^{2}$ Faculdade de Farmácia, Departamento de Produtos \\ Farmacêuticos, Universidade Federal de Minas Gerais, Avenida Presidente Antônio Carlos, 6627, CEP: $31270-$ \\ 901, Campus UFMG - Pampulha, Belo Horizonte-Brasil *roc2006@farmacia.ufmg.br 3Instituto de Ciências \\ Exatas e Naturais, Universidade Federal do Mato Grosso, Campus Universitário de Rondonópolis, Rodovia \\ Rondonópolis-Guiratinga, km 6, CEP: 78735-901, Rondonópolis-Brasil
}

\begin{abstract}
The purpose of this study was to screen the antioxidant activity of medicinal plant extracts from the Brazilian cerrado, through other methods than the total phenolic content and its correlation with the antioxidant activity. Ethanolic extracts of ten species were evaluated through three antioxidant assays, in vitro, including 2,2-diphenyl-1-picrylhydrazyl (DPPH), total antioxidant activity and reducing power; and by using the Folin-Ciocalteu method the total phenolic content was determined. Ethanolic extracts of Stryphnodendron obovatum, Cecropia pachystachya and Duguetia furfuraceae showed strong antioxidant activity $\left(\mathrm{IC}_{50}<5 \mu \mathrm{g} \mathrm{mL}^{-1}\right)$ in the DPPH free radical scavenging assay; the species Vernonia phosphorea, Hymenaea stignocarpa and Jacaranda ulei may also be highlighted. These results were confirmed in the assays of total antioxidant capacity and reducing power. The extracts of $S$. obovatum and $V$. phosphorea showed an abundant phenolic content; therefore, the phenolic content may play a role in the antioxidant activity. These two species, traditionally used in Brazil, showed great power in these assay systems and may be a promising source for the development of natural antioxidants and future candidates for phytochemical and pharmacological studies in related diseases.
\end{abstract}

Keywords: antioxidant potential, total phenolic content, Stryphnodendron obovatum, Vernonia phosphorea

RESUMO: Avaliação da propriedade antioxidante de espécies do cerrado no Brasil detectada por diferentes ensaios. O objetivo desse trabalho foi triar a atividade antioxidante de extratos de plantas medicinais do cerrado do Brasil, por outros métodos além do conteúdo de fenóis totais e sua correlação com a atividade antioxidante. Assim, o extrato etanólico de dez espécies vegetais do cerrado brasileiro foi avaliado por três ensaios de atividade antioxidante, in vitro: 2,2-difenil-1-picrilhidrazil (DPPH); atividade antioxidante total e poder redutor; e o teor de fenóis determinado pelo reagente de Folin-Ciocalteu. O extrato etanólico de Stryphnodendron obovatum, Cecropia pachystachya e Duguetia furfuraceae apresentaram forte atividade antioxidante $\left(\mathrm{Cl}_{50}<5 \mathrm{mg} \mathrm{mL}^{-1}\right)$ no ensaio com o DPPH, tendo destaque também as espécies Vernonia phosphorea, Hymenaea stignocarpa e Jacaranda ulei. Os extratos de $S$. obovatum e $V$. phosphorea demonstraram maiores teores de fenóis, indicando que esse grupo de substâncias possa ser a responsável pela atividade antioxidante. Essas duas espécies, usadas tradicionalmente no Brasil, representam fontes promissoras para o desenvolvimento de antioxidantes naturais e futuros estudos fitoquímicos e farmacológicos em doenças relacionadas.

Palavras-chave: potencial antioxidante, fenóis totais, Stryphnodendron obovatum, Vernonia phosphorea

\section{INTRODUCTION}

There has been an increasing interest in natural antioxidants, present in medicinal and dietary plants, which might help prevent oxidative stress. Oxidative stress is the result of the imbalance between the antioxidant defense system and the formation of oxygen free radicals, that is, reactive oxygen species (ROS). Free radicals are caused by various environmental chemicals as well as

Recebido para publicação em 19/05/2010

Aceito para publicação em 06/02/2013

Rev. Bras. PI. Med., Campinas, v.15, n.4, p.520-528, 2013. 
endogenous metabolism (Ichihashi et al., 2004). ROS may damage important membrane lipids, proteins, DNA and carbohydrates (Nohl et al., 2005; Halliwell et al., 1999; Halliwell et al., 1992). The damage may cause cell injury and death, and exacerbate the development of several agingrelated chronic diseases, including atherosclerosis, diabetes, cardiovascular diseases and cancer (Masella et al., 2005; Yesilada et al., 2000; Kasai et al., 2000; Jin \& Chen, 1998).

Sources of natural antioxidants are primarily phenolics of plants that may occur in all parts of the plant such as fruits, vegetables, nuts, seeds, leaves, roots and barks. Phenolics of plants are multifunctional and can act as reducing agents (free radical terminators), metal chelators and singlet oxygen quenchers. The most common phenolic antioxidant of plants include tannins, flavonoids, cinnamic acid derivatives, coumarins, tocopherols and polyfunctional organic acids. Consumption of antioxidants from plant materials that inhibit free radical formation or accelerate their elimination has been associated with a lowered incidence of these diseases as a consequence of oxidative stress alleviating of free radicals (Leong \& Shui, 2002; Ames, 1983; Hertog et al., 1993). Recently, interest has increased considerably in finding naturally occurring antioxidants for use in foods, as a replacement for synthetic antioxidants, such as $\mathrm{BHA}$ and buthylated hydroxytoluene (BHT), which have had their use restricted due to their side effects such as carcinogenesis (Storz, 2005; Gutteridge, 1993; Kehrer, 1993) or medicinal materials (Dinesh \& Ghosh, 2012; Lönn, et al., 2012; Psaltopoulou et al., 2011; El-barbary et al., 2011 ;Collins, 2005).

There are several experimental models in vitro to determine the antioxidant activity of substances, such as DPPH, ABTS, â-carotene beaching, ferro ion chelanting, and others. In general, this assays have the different mechanisms of antioxidant activity (Mathew \& Abraham, 2006). The concentration of the antioxidant and structure are better defined and controlled during in vitro as compared to in vivo studies. Although in vivo studies are more realistic, they are also incredibly multi-faceted, with factors such as its antioxidant metabolism and instability. Studies, in vitro, are controlled more simply, being important in the initial deduction of the characteristics of a new series of antioxidants. Thus, health effects and mode of action of antioxidants can be elucidated and it is important to confirm the results by different assays (Haenen et al., 2006).

The aim of this study was to screen medicinal plant extracts of Brazil cerrado origin for their potential antioxidant activity, using different assays such as reducing power, total antioxidant activity and free radical scavenging by the 2,2-diphenyl1-picrylhydrazyl (DPPH) to confirm the proton and electron donating mechanism. Additionally, the total phenolic content from plant extracts was measured and their correlation with the antioxidant activities was ascertained by using the Pearson correlation coefficient.

\section{MATERIAL AND METHOD}

\section{Plant Materials}

The plant materials were collected, 2003, in the reserve in the Campus of the Universidade

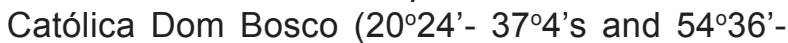
$52^{\circ} 5^{\prime} \mathrm{w}$, mean altitude between 569 and $640 \mathrm{~m}$ ) in the State of Mato Grosso do Sul, Brazil, and identified by the botanists Dr. Arnildo Pott, Dra Vali J. Pott (CNPGC/EMBRAPA) and Dra Ubirazilda Maria Resende (Universidade Federal do Mato Grosso do Sul). Voucher specimens are kept for reference in the HMS Herbarium - CNPGC/EMBRAPA) and Herbarium of the Universidade Federal do Mato Grosso do Sul in the city of Campo Grande (CGMS) (Table 1).

\section{Preparation of extracts}

Dried leaves, roots and barks $(1 \mathrm{Kg})$ of the plants were pulverized and subjected to successive extraction by maceration with hexane and ethanol with replace of solvent until exhaustion. The solvents were evaporated under reduced pressure to give a solid residue.

\section{DPPH free radical scavenging assay}

The hydrogen atom or electron donation ability of the corresponding extracts was measured from the bleaching of purple colored ethanol solution of 2,2-diphenyl-1-picrylhydrazyl (DPPH Sigma Aldrich) (Brand-Williams et al., 1995). The $\mathrm{DPPH}$ is a stable radical that accepts an electron or hydrogen radical to become a stable (Soares et al., 1997). Ethanolic solutions $(2.5 \mathrm{~mL})$ of various concentrations of the extracts in hexane and ethanol $\left(5,10,25,50,125\right.$ and $\left.250 \mathrm{mg} \mathrm{mL}^{-1}\right)$ were added to $1 \mathrm{~mL}$ of an ethanol solution of DPPH (0.3 mM). After a 30 min incubation period at room temperature, the absorbance was read against a blank at $\lambda 516 \mathrm{~nm}$. Free radical DPPH inhibition in percentage $(1 \%)$ was calculated as follows:

$$
1 \%=\left(A_{\text {blank }}-A_{\text {sample }} / A_{\text {blank }}\right) \times 100
$$

where $A_{\text {blank }}$ is the absorbance of the control reaction (containing all reagents except the test compound or extract), and $\mathrm{A}_{\text {sample }}$ is the absorbance of the test extract. Extract concentration providing 
TABLE 1. Botanical data and medicinal uses of Brazilian cerrado plants studied.

\begin{tabular}{|c|c|c|c|c|}
\hline Botanical name & Family & Part plant & Voucher & Medicinal uses \\
\hline $\begin{array}{l}\text { Bowdichia virgiloides } \\
\text { Kunth. }\end{array}$ & Fabaceae & Leaves & CGMS 11966 & $\begin{array}{l}\text { Anti-inflammatory and antinoceptive potential (Thomazzia } \\
\text { et al., 2010; Silva et al., 2010; Barros et al., 2010) }\end{array}$ \\
\hline $\begin{array}{l}\text { Cecropia } \\
\text { pachystachya Trécul }\end{array}$ & Cecropiaceae & Leaves & CGMS 11697 & $\begin{array}{l}\text { Cardiotonic, sedative and hypoglycemic activities (Aragão } \\
\text { et al., 2010; Consolini et al., 2006;) }\end{array}$ \\
\hline $\begin{array}{l}\text { Duguetia furfuraceae } \\
\text { (St. Hil) Benth. \& Hook }\end{array}$ & Annonaceae & Leaves & HMS 4445 & Rheumatism and renal colic (Rodrigues \& Carvalho, 2001) \\
\hline Hymenaea courbaril L. & Fabaceae & Leaves & CGMS 11696 & $\begin{array}{l}\text { Diarrhoea, dysentery, intestinal colic, cystitis, antiviral } \\
\text { activity and inhibition of 5-lipoxygenase (Cecílio et al., } \\
\text { 2012; Lorenzi \& Matos, 2002; Braga et al., 2000; Panizza, } \\
\text { 1997) }\end{array}$ \\
\hline $\begin{array}{l}\text { Hymenaea } \\
\text { stignocarpa Mart. ex. } \\
\text { Hayne }\end{array}$ & Fabaceae & Leaves & CGMS 11695 & $\begin{array}{l}\text { Antidiarrheal, gastro-protective and cicatrising activities } \\
\text { (Orsi et al., 2012) }\end{array}$ \\
\hline $\begin{array}{l}\text { Jacaranda ulei Bureau } \\
\& \text { K. Schum. }\end{array}$ & Bignoniaceae & Leaves/Roots & CGMS 11972 & $\begin{array}{l}\text { Jacaranda species are used for blenorrhagy, skin ulcers, } \\
\text { anti-syphilis and anti-gonorrhoea, and anti-inflammatory } \\
\text { remedies (Gachet \& Schühly, 2009) }\end{array}$ \\
\hline $\begin{array}{l}\text { Melacium campestre } \\
\text { Naudin }\end{array}$ & Cucurbitaceae & Leaves & HMS4441 & $\begin{array}{l}\text { Struthanthus species are used in parasitosis and skin } \\
\text { disorders (Martinez \& Barboza, 2010) }\end{array}$ \\
\hline $\begin{array}{l}\text { Struthanthus cf } \\
\text { polyrhizus Mart. }\end{array}$ & Loranthaceae & Leaves & CGMS 11700 & $\begin{array}{l}\text { Wound-healing, anti-inflammatory, anti-ulcerogenic, } \\
\text { anti-tyrosinase and Molluscicidal activities (Lopes et. al, } \\
\text { 2005; Rebecca et al., 2003; Baurin et al., 2002; Bezerra } \\
\text { et al., 2002) }\end{array}$ \\
\hline $\begin{array}{l}\text { Stryphnodendron } \\
\text { obovatum Benth. }\end{array}$ & Fabaceae & Bark & CGMS 32997 & - \\
\hline $\begin{array}{l}\text { Vernonia phosphorea } \\
\text { Vell. }\end{array}$ & Asteraceae & Leaves & CGMS 11970 & $\begin{array}{l}\text { Antimalarial, anticancer, hypoglycaemic (Masaba, 2000; } \\
\text { Izevbigie et al., 2008) }\end{array}$ \\
\hline
\end{tabular}

$50 \%$ inhibition $\left(\mathrm{IC}_{50}\right)$ was calculated from the graph plotted inhibition percentage against extract concentration. Tests were carried out in triplicate and butylated hydroxytoluene (BHT), quercetin and rutin (all from Sigma Aldrich) in the same concentrations were used as positive controls.

\section{Determination of total antioxidant capacity}

The antioxidant activity of the extracts was evaluated by using the phosphomolybdenum method according to the procedure of Prieto et al. (1999). The assay is successfully used to quantify vitamin $\mathrm{E}$ in seeds and, being simple and independent of other antioxidant measurements commonly employed. The assay is based on the reduction of $\mathrm{Mo}(\mathrm{VI})-$ $\mathrm{Mo}(\mathrm{V})$ by the extract and subsequent formation of a green phosphate/Mo(V) complex at acid $\mathrm{pH} .0 .3$ $\mathrm{mL}$ ethanolic extracts were combined with $2.7 \mathrm{~mL}$ of reagent solution ( $0.6 \mathrm{M}$ sulfuric acid, $28 \mathrm{mM}$ sodium phosphate and $4 \mathrm{mM}$ ammonium molybdate). The tubes containing the reaction solution were incubated at $95^{\circ} \mathrm{C}$ for $90 \mathrm{~min}$. Then the absorbance of the solution was measured at I $695 \mathrm{~nm}$ using a spectrophotometer against blank after cooling to room temperature. Ethanol $(0.3 \mathrm{~mL})$ in the place of extract is used as the blank. Tests were carried out in triplicate and butylated hydroxytoluene $(\mathrm{BHT})$, quercetin and rutin in the same concentration were used as positive controls. Antioxidant capacities of samples were expressed as ascorbic acid equivalents ( $\mathrm{mmol} \mathrm{mg}^{-1}$ of plant extract).

\section{Reducing power}

Reducing power of the ethanolic extracts obtained was determined by the method explained by Oyaizu (1986). In this assay, the antioxidant activity of the samples was measured by their ability to reduce the $\mathrm{Fe}^{3+} /$ ferricyanide complex by forming ferrous products. $\mathrm{Fe}^{2+}$ can be monitored by measuring the formation of Perl's Prussian blue. 1.0 $\mathrm{mL}$ of ethanol containing different concentrations of samples were mixed with $2.5 \mathrm{~mL}$ of phosphate buffer (0.2 M, pH 6.6) and $2.5 \mathrm{~mL}$ potassium ferricyanide $(1 \%)$. Reaction mixture was incubated at $50^{\circ} \mathrm{C}$ for $20 \mathrm{~min}$. After incubation, $2.5 \mathrm{~mL}$ of trichloroacetic acid $(10 \%)$ was added and centrifuged at $3000 \mathrm{rpm}$ for $10 \mathrm{~min}$. From the upper layer, $2.5 \mathrm{~mL}$ solution was mixed with $2.5 \mathrm{~mL}$ distilled water and $0.5 \mathrm{~mL}$ 
$\mathrm{FeCl} 3(0.1 \%)$. Absorbance of all the sample solutions was measured at I $700 \mathrm{~nm}$. Increased absorbance indicates increased reducing power (Meir et al, 1995; Kumaran \& Karunakaran, 2007). Tests were carried out in triplicate and butylated hydroxytoluene (BHT), quercetin and rutin in the same concentrations were used as positive controls. Antioxidant capacities of samples were expressed as ascorbic acid equivalents ( $\mathrm{mmol} \mathrm{mg}^{-1}$ of plant extract).

\section{Determination of total phenolics}

Total phenolic content of extracts was assessed by using the Folin-Ciocalteau phenol reagent method (Fonseca \& Librandi, 2008). The extracts were diluted with the same solvent used for extraction to a suitable concentration for analysis. To $1 \mathrm{~mL}$ of the sample extracts were added $5.0 \mathrm{~mL}$ of Folin-Ciocalteau reagent and $4 \mathrm{~mL}$ of sodium carbonate $(7.5 \% \mathrm{w} / \mathrm{v})$, and the contents were mixed and allowed to stand for $5 \mathrm{~min}$ in $50^{\circ} \mathrm{C}$. Absorption at I $765 \mathrm{~nm}$ was measured in a UV-Vis Spectrophotometer. The total phenolic content was expressed as gallic acid equivalents $\left(\mathrm{mg} \mathrm{g}^{-1}\right.$ of plant extract), using an analytical curve generated with gallic acid (Sigma Aldrich).

\section{Statistical analysis}

The data were analyzed by repeated measures of one-way analysis of variance (ANOVA) with Tukey post test and the correlation of total phenolic and antioxidant activities (DPPH) was analysed by Pearson rank correlation coefficient. using SPSS Version 6.0. Significance was set at $5 \%$.

\section{RESULT AND DISCUSSION}

In the search for plants with antioxidant activity and pharmacological potential, were tested extracts of native species from Brazilian cerrado flora. The choice of the species was focused on plants traditionally used in Brazil for their relation with antioxidant properties, as anti-inflammatory, as well as nonspecific symptoms which could be frequently described as inflammatory origin, cancer and diabetes. Selected plant species, the parts of plants used for extraction, the voucher number and the medicinal uses are shown in Table 1. Different parts of ten plants of the seven families were extracted with hexane and ethanol. The extracts obtained were screened for their possible antioxidant activity by using three test systems; $\mathrm{DPPH}$ free radical scavenging, determination of total antioxidant capacity and reducing power to confirm the mechanism of proton and electron donating abilities (Haenen et al., 2006) and the Folin-Ciocalteu method to determine the amount of total phenolics and the correlation with this action.
As expected, the DPPH activity test results from the experiments indicated the superiority of the polar extracts to the non-polar extracts studied. The hexanic extract of $B$. virgiloides, $H$. courbaril and $H$. stignocarpa did not show any activity (Table 2 ). The effect of methanol extracts are better than hexanic in C. pachystachya, D. furfuraceae, S. cf. polyrhizus and $S$. obovatum. The best scavenging effect of hexanic extracts was $M$. campestre. The scavenging effect of the three best methanol extracts with the DPPH radical is in the following order: $S$. obovatum, C. pachystachya, $D$. furfuraceae (Table 2).

The total antioxidant capacity is given in Table 2. The study reveals that the ethanol extract of $S$. obovatum seems to be having a higher capacity than the other speciesf. The decreasing antioxidant activities of the plant species are in this order: S. obovatum, V. phosphorea, H. stignocarpa, C. pachystachya, $D$. furfuraceae, leaves $\mathrm{J}$. ulei $=$ roots J. ulei, S. cf. polyrhizus and $H$ courbaril $=B$. virgiloides $=M$. campestre.

The results of reductive capabilities of the ethanolic extracts show that the ethanolic extract of $S$. obovatum possesses higher capacity than other species (Table 2). The reducing power of ethanolic extract of plants followed the decreasing order: S. obovatum, V. phosphorea, leaves J. ulei, $H$. stignocarpa, D. furfuraceae, C. pachystachya, $B$. virgiloides, $H$ courbaril = M. campestre, roots J. ulei, S. cf polyrhizus.

The colorimetric analysis of total phenolics of ethanolic extracts is based on the absorbance values of the extracts solutions which reacted with Folin-Ciocalteu reagent as described in methods. The results are show in Figure 1. The amount of the total phenolics was highest in S. obovatum, followed by $V$. phosphorea roots and leaves of $J$. ulei. The amount of the total phenolics was lowest in $M$. campestre. The Folin-Ciocalteu assay, one method used for quantitative analysis of total phenols is based on the reaction of Folin-Ciocalteu reagent with the functional hydroxy groups of phenolic compounds. Currently the Folin-Ciocalteu assay has also been used to quantify the antioxidant activity (Michalska et al., 2008).

There is a strong correlation in amount of the total phenolics of ethanolic extracts and antioxidant activity (DPPH) (Pearson test, $r=0.98, p £ 0.01$ ). $S$. obovatum and $V$. phosphorea, which possesses the best antioxidant activity potential, possesses the highest amount of the total phenolics.

According to the results, the ethanolic extracts of S. obovatum, C. pachystachya and $D$. furfuracea showed strong, in vitro, antioxidant activity in DPPH free radical scavenging assay; S. obovatum, V. phosphorea and H. stignocarpa ethanolic extracts in vitro total antioxidant capacity 
TABLE 2. IC $\mathrm{I}_{50}$ values against DPPH, total antioxidant capacity and reducing power of Brazilian cerrado plants.

\begin{tabular}{|c|c|c|c|c|}
\hline \multirow[t]{2}{*}{ Botanical name } & \multicolumn{2}{|c|}{$\begin{array}{c}\text { IC50 } \\
\left(\mu \mathrm{g} \mathrm{mL}^{-1}\right)^{\star}\end{array}$} & \multirow{2}{*}{$\begin{array}{c}\text { Total } \\
\text { antioxidant } \\
\text { capacity** }^{*}\end{array}$} & \multirow{2}{*}{$\begin{array}{c}\begin{array}{c}\text { Reducing } \\
\text { power** }\end{array} \\
\text { Dried } \\
\text { ethanolic } \\
\text { extract }\end{array}$} \\
\hline & $\begin{array}{c}\text { Dried } \\
\text { hexanic } \\
\text { extract }\end{array}$ & $\begin{array}{c}\text { Dried } \\
\text { ethanolic } \\
\text { extract }\end{array}$ & & \\
\hline Bowdichia virgiloides Kunth. & - & $5.26 \pm 0.01$ & $120.14 \pm 3.23$ & 131.130 .88 \\
\hline Cecropia pachystachya Trécul & $8.60 \pm 0.78$ & $2.15 \pm 0.24$ & $186.78 \pm 1.49$ & $140.66 \pm 0.96$ \\
\hline Duguetia furfuraceae (St. Hil) Benth. \& Hook & $8.71 \pm 0.52$ & $3.40 \pm 0.28$ & $152.95 \pm 0.68$ & $146.12 \pm 3.82$ \\
\hline Hymenaea courbaril L. & - & $4.18 \pm 1.93$ & $123.69 \pm 0.74$ & 125.82 .75 \\
\hline Hymenaea stignocarpa Mart. ex. Hayne & - & $10.21 \pm 1.17$ & $202.03 \pm 0.75$ & $176.86 \pm 1.54$ \\
\hline Jacaranda ulei Bureau \& K. Schum.Leaves & $8.92 \pm 1.43$ & $6.38 \pm 0.06$ & $138.23 \pm 1.46$ & $187.78 \pm 1.14$ \\
\hline Jacaranda ulei Bureau \& K. Schum.Roots & $5.02 \pm 4.69$ & $8.54 \pm 0.55$ & $135.13 \pm 2.57$ & $138.24 \pm 0.76$ \\
\hline Melacium campestre Naudin & $4.46 \pm 0.07$ & $4.53 \pm 0.09$ & $118.21 \pm 3.54$ & $120.13 \pm 2.30$ \\
\hline Struthanthus cf polyrhizus Mart. & $8.87 \pm 0.37$ & $5.29 \pm 0.02$ & $132,48 \pm 0.85$ & $118.81 \pm 0.58$ \\
\hline Stryphnodendron obovatum Benth. & $5.46 \pm 0.95$ & $0.80 \pm 0.25$ & $393.41 \pm 2.18$ & $312,76 \pm 1.00$ \\
\hline Vernonia phosphorea Vell. & $23.48 \pm 10.11$ & $15.85 \pm 0.88$ & $215.81 \pm 1.49$ & $207.97 \pm 1.00$ \\
\hline $\mathrm{BHT}$ & & $2.66 \pm 0.08$ & $228.51 \pm 3.25$ & $355.70 \pm 0.96$ \\
\hline Rutin & & $1.39 \pm 0.01$ & $168,93 \pm 2.14$ & $253.96 \pm 2.48$ \\
\hline Quercetin & & $0.40 \pm 0.22$ & $245.34 \pm 3.22$ & 515.74 \\
\hline
\end{tabular}

Results are expressed as mean $\pm \mathrm{SD}, \mathrm{n}=3$.

${ }^{*} \mathrm{IC}_{50}$ : concentration of drug in $\mathrm{mg} \mathrm{mL}^{-1}$ that caused $50 \%$ of DPPH inhibition.

${ }^{* *} \mathrm{mmol}$ ascorbic acid $\mathrm{mg}^{-1}$ of dried ethanolic extract; concentration of extracts used $=50 \mathrm{mg} \mathrm{mL}^{-1}$.

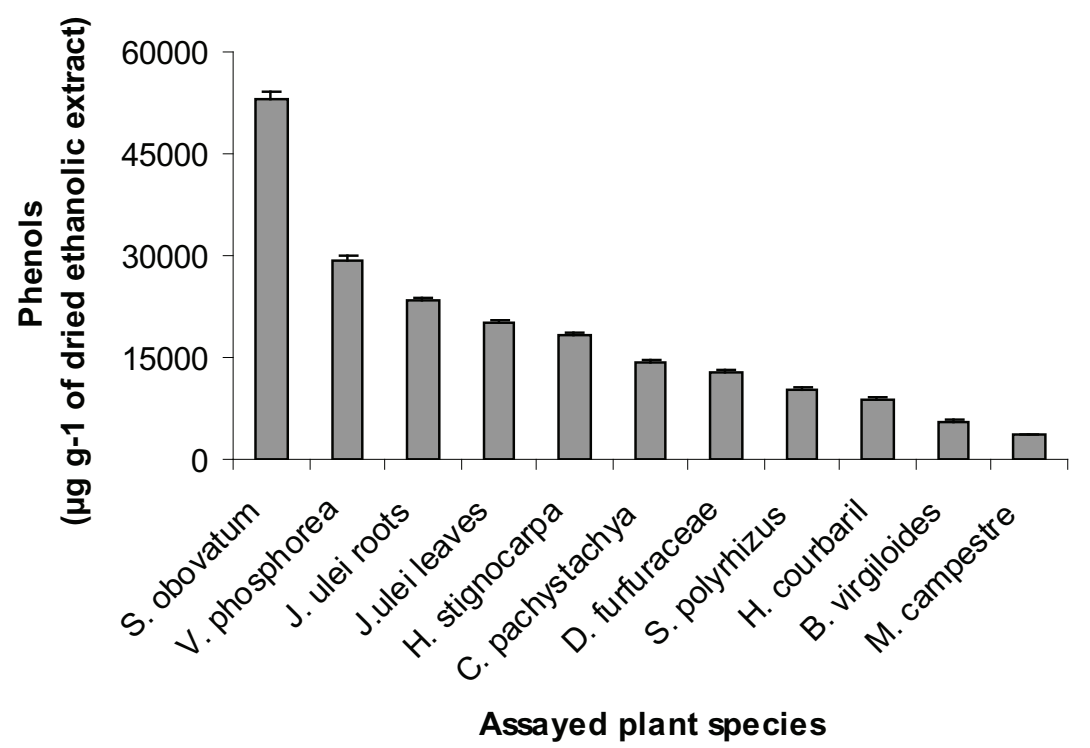

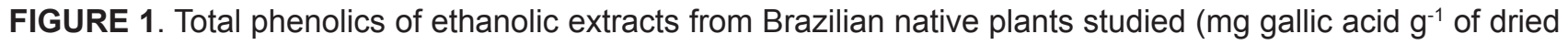
ethanolic extract). Results are mean $\pm \operatorname{SD}(n=3)$. 
test, while in vitro reducing power test $S$. obovatum, $V$. phosphorea and leaves of Jacaranda ulei. With some small variations, the three antioxidants assays were able to confirm the proton and electron donating of the extracts evaluated. By using the FolinCiocalteu method to determine the total phenolic and antioxidant activity, it was shown that these extracts contain abundant phenolics, mainly $S$. obovatum and $V$. phosphorea. In addition, V. phosphorea also contained rich and effective phenolics in the reducing power and total antioxidant tests but they are not so effective in the DPPH system. This may be attributed to the compounds of plant extracts possessing small differences in their proton and electron donating abilities (Rice-Evans et al., 1996). It is important to point out that there is a positive correlation between antioxidant activity potential and amount of phenolic compounds of the extracts, because this substances can act as reducing agents, metal chelators and singlet oxygen quenchers (Leong \& Shui, 2002). Thus, the total phenolics may play a role in the antioxidant activity (Duthie \& Crozier, 2000).

Several simple bioassays were developed for screening purposes, in an effort to discover new lead compounds. Many research groups screen plant extracts of Brazilian biomes, like Cerrado, Atlantic Forest, Amazon and Caatinga to detect bioactive substance (Cecílio et al., 2012; Tretin et al., 2011; Mesquita et al, 2009; Pavan et al., 2009; Cardoso-Lopes, 2008; Alves et al., 2000).

According to Myers et al. (2000) Atlantic Forest and Cerrado are part of the 25 global biodiversity hotspots. Together, these hotspots contain $44 \%$ of all plant species are endemic. Thus, these biomes are rich in endemism, so an important source of bioactive substance.

There is tremendous amount of reports of plants as antioxidants under various disease conditions like diabetes, cancer, atherosclerosis and arthritis, showing that the mechanism involved in treatment of these diseases may be also with antioxidants (Dinesh \& Ghosh, 2012; Lönn, et al., 2012; Psaltopoulou et al., 2011; El-barbary et al., 2011 ;Collins, 2005). From the study, it is evident that most plants from cerrado in Brazil possess potent antioxidant activity, mainly, S. obovatum and $V$. phosphorea. S. obovatum, popularly known, in Brazil, as "barbatimão", is used traditionally by the local population to treat leucorrhea and diarrhea, as anti-inflammatory and antiseptic agents and to promote wound healing (Rizzini, 1997). Studies of Stryphnodendron species have demonstrated that these have significant wound-healing, antiinflammatory, anti-ulcerogenic, anti-tyrosinase and Molluscicidal activities (Table 1). The chemical composition of this genera have shown mainly tannins (Mello et al., 1996a; 1996b; 1999). Lopes et al. (2005) demonstrated that S. polyphyllum showed DPPH free radical scavenging activity between $70.10 \%$ and $74.78 \%$ and S. obovatum nearly half this value $(35.85 \%$ to $36.40 \%)$ at a concentration of $4 \mathrm{~g} \mathrm{~mL}^{-1}$ and its activity of both species probably favored cicatrisation of cutaneous wounds.

Vernonia phosphorea, popularly known, in Brazil, as "assa peixe", is used traditionally by the local population to treat asthma bronquial, cough, hemorrhoid, diabetic, diuretic, wound-healing, rheumatism and expectorant agent (Côrrea, 1962). Studies of Vernonia species have demonstrated that these have numerous activities: antimalarial , anticancer, hypoglycaemic (Table 1). Phytochemical studies of these species have revealed among others the presence of sesquiterpene lactones, steroids and flavonoids (Tian et al., 2004; Suo et al., 2008; Erasto et al., 2006). Erasto et al. (2007) demonstrated that the methanol extract of $V$. amygdalina exhibited high activity, by scavenging $75-99.3 \%$ of the DPPH radicals. But there is no study about free radical scavenging activity in V. phosphorea, this is the first study.

Previous phytochemical studies of Cecropia pachystachya have shown the presence of flavonoids and tannins. Aragão and collaborators (2010) demonstrated that methanolic extract of Cecropia pachystachya possesses hypoglycemic and antioxidant effects with $\mathrm{IC}_{50}=3.1 \mathrm{ig} / \mathrm{ml}(\mathrm{DPPH}$ assay), which confirmed the traditional use of the plant in the treatment of diabetes (Tabela 1). Chlorogenic acid and the $\mathrm{C}$-glycosylated flavonoids may explain these activities, showing that our results are in good agreement with the medicinal use of this species.

In the most biological screening of multiple plant extracts, Jacaranda presented activity against specific biological targets (Tabela 1). For example, it has been cited that "garrafada", a remedy prepared with roots and leaves of $J$. decurrens in wine, is used to treat syphilis, rheumatism, inflammation and skin diseases (Maroni et al., 2006). The ethanol extract from bark of $J$. acutifolia is used against rheumatism and sciatica. The decoction of leaves from J. copaia is drunk to treat rheumatism and the infusion of leaves in a bath to heal general weakness and fever (Gachet \& Schühly, 2009). Phytochemistry studies of Jacaranda genus have shown that it is source of phenolics, including arilethanoids of cinnamoyl glucosides, as verbascoside (Martin, et al., 2009; Arruda et al., 2011).

Considering that the species studied occurs in an ecosystem with a high degree of endemism and its ethnomedicinal uses (Tabela 1), it is feasible to infer that they should be a potential source of bioactive compounds. Several studies are going on throughout the world seeking to identify 
antioxidant compounds that are pharmacologically potent (Dinesh \& Ghosh, 2012; Lönn, et al., 2012; Psaltopoulou et al., 2011; El-barbary et al., 2011; Aragão et al., 2010; Mesquita et al, 2009; Collins, 2005).

The high presence of phenolics and the antioxidant activity of the three studied species have validated the importance of $S$. obovatum, $V$. phosphorea, and C. pachystachya as medicinal plants. Thus, a more focused research and understanding is required to validate this species as foods or/and drugs for treatment of ROS related diseases.

\section{ACKNOWLEDGEMENT}

To CNPq, FAPEMIG, FUNDECT for financial support and fellowships (FARIAS, K.S. and SANTOS, T.S.N.).

\section{REFERENCE}

ALVES, T.M.A. et al. Biological Screening of Brazilian Medicinal Plants. Memórias do Instituto Oswaldo Cruz, v.95, p.367-73, 2000.

AMES, B.N. Dietary carcinogens and anticarcinogens: oxygen radicals and degenerative disease. Science, v.221, p.1256-63, 1983.

ARAGÃO, D.M.O. et al. Hypoglycemic effects of Cecropia pachystachya in normal and alloxan-induced diabetic rats. Journal of Ethnopharmacology, v.128, p.62733, 2010.

BARROS, W.M. et al. Anti-inflammatory effect of the ethanolic extract from Bowdichia virgilioides H.B.K stem bark. Anais da Academia Brasileira de Ciências, v.82, p.609-16, 2010.

ARRUDA, A.L.A. et al. Jacaranda cuspidifolia Mart. (Bignoniaceae) as Antibacterial Agent. Journal of Medicinal Food, v.14, p.1-5, 2011.

BAURIN, N. et al. Preliminary screening of some tropical plants for anti-tyrosinase activity. Journal of Ethnopharmacology, v.82, p.155-8, 2002.

BEZERRA, J.C.B. et al. Molluscicidal activity against Biomphalaria glabrata of Brazilian Cerrado medicinal plants. Fitoterapia, v.73, p.428-30, 2002.

BRAGA, F.C. et al. Screening Brazilian plant species for in vitro inhibition of 5-lipoxygenase. Phytomedicine, v.6, p.447-52, 2000.

BRAND-WILLIAMS, W. et al. Use of a free radical method to evaluate antioxidant activity. LebensmittelWissenschaft und-Technologie, v.28, p.25-30, 1995.

CARDOSO-LOPES, E.M. et al. Screening for antifungal, DNA-damaging and anticholinesterasic activities of Brazilian plants from the Atlantic Rainforest - Ilha do Cardoso State Park. Revista Brasileira de Farmacognosia, v.19, p.655-60, 2008.

CECÍLIO, A.B. et al. Screening of Brazilian medicinal plants for antiviral activity against rotavirus. Journal of Ethnopharmacology, v.141, p. 975-81, 2012.

COLLINS, A.R. Antioxidant intervention as a route to cancer prevention. European Journal of Cancer, v.41, p.1923-30, 2005.

CONSOLINI, A.E. et al. Cardiotonic and sedative effects of Cecropia pachystachya Mart. (ambay) on isolated rat hearts and conscious mice. Journal of Ethnopharmacology, v. 106, p. 90-96, 2006.

CÔRREA, M.P. Dicionário de plantas úteis do Brasil. Rio de Janeiro: Editora Imprensa Nacional, Ministério da Agricultura, 1962.

DINESH, T.; GHOSH, R. Antioxidants for prostate cancer chemoprevention: Challenges and opportunities. Biochemical Pharmacology, v.83, p.1319-30, 2012.

DUTHIE, G.; CROZIER, A. Plant-derived phenolic antioxidants. Current Opinion in Clinical Nutrition \& Metabolic Care, v.3, p.447-51, 2000.

EL-BARBARY, A.M. et al. Assessment of lipid peroxidation and antioxidant status in rheumatoid arthritis and osteoarthritis patients The Egyptian Rheumatologist, v.33, p.179-85, 2011.

ERASTO, G. et al. Bioactive sesquiterpene from leaves of Vernonia amygdalina. Journal of Ethnopharmacology, v.106, n.1, p.117-29, 2006.

ERASTO, P. et al. Evaluation of antioxidant activity and the fatty acid profile of the leaves of Vernonia amygdalina growing in South Africa. Food Chemistry, v.104, p.63642, 2007.

FONSECA, P.; LIBRANDI, A.P.L. Avaliação das características físico-químicas e fitoquímicas de diferentes tinturas de barbatimão (Stryphnodendron barbatiman). Revista Brasileira de Ciências Farmacêuticas, v.44, p.271-277, 2008.

GACHET, M.; SCHÜHLY, W. Jacaranda - An ethnopharmacological and phytochemical review. Journal of Ethnopharmacology, v.121, p.14-27, 2009.

GUTTERIDGE, J.M.C. Free radicals in diseases processes: a compilation of cause and consequence. Free Radical Research Communications, v.19, p.14158, 1993.

HAENEN, G.R.M.M. et al. Structure and activity in assessing antioxidant activity in vitro and in vivo: A critical appraisal illustrated with the flavonoids. Environmental Toxicology and Pharmacology, v. 21, p. 191-8, 2006.

HALLIWELL, B. Antioxidant defense mechanisms: from the beginning to the end. Free Radical Research Communications, v.31, p.261-72, 1999.

HALLIWELL, B. et al. Free radicals, antioxidants, and human disease: where are we now? Journal of Laboratory and Clinical Medicine, v.119, p.598-620, 1992.

HERTOG, M.G.L. et al. Dietary antioxidant flavonoids and risk of coronary heart disease: the Zutphen elderly study. The Lancet, v.342, p.1007-11, 1993.

ICHIHASHI, M. et al. UV-induced skin damage. Toxicology, v.189, p.21-39, 2003.

IZEVBIGIE, E.B. Amygdalina: folk medicine, analysis, and potential application for cancer treatment. Current Pharmaceutical Analysis, v.4, n.1, p.20-4, 2008.

JIN, Z.Q.; CHEN, X. A simple reproducible model of free radical-injured isolated heart induced by 1,1-diphenyl2-picrylhydrazyl (DPPH). Journal of Pharmacological and Toxicological Methods, v.39, p.63-70, 1998.

KASAI, $\mathrm{H}$. et al. Action of chlorogenic acid in vegetable and fruits as an inhibitor of 8-hydroxydeoxyguanosine 
formation in vitro and in a rat carcinogenesis model. Food and Chemical Toxicology, v.38, p.467-71, 2000.

KEHRER, J. Free radicals as mediators of tissue injury and disease. Critical Reviews in Toxicology, v.23, p.21-48, 1993.

KUMARAN, A.; Karunakaran, R.J. In vitro antioxidant properties of methanol extracts of five Phillanthus species from India. Food Science and Technology, v.40, p.344-52, 2007

LEONG, L.P.; SHUI, G. An investigation of antioxidant capacity of fruits in Singapore markets. Food Chemistry, v.76, p.69-75, 2002.

LÖNN, M.E. et al. Actions of "antioxidants" in the protection against atherosclerosis. Free Radical Biology and Medicine, v.53, p.863-84, 2012.

LOPES, G.C. et al. Influence of extracts of Stryphnodendron polyphyllum Mart. and Stryphnodendron obovatum Benth. on the cicatrisation of cutaneous wounds in rats. Journal of Ethnopharmacology, v.99, p.265-72, 2005.

LORENZI, H.; MATOS, F.J.A. Plantas Medicinais no Brasil: nativas e exóticas. 2.ed. Nova Odessa: Editora Plantarum, 2002, 384p.

MARONI, B.C. et al. Plantas medicinais do cerrado de Botucatu: Guia ilustrado. São Paulo: Editora UNESP, 2006, 194p.

MARTIN, F. et al. Antioxidant Phenylethanoid Glycosides and a Neolignan from Jacaranda caucana. Journal of Natural Products, v.72, p.852-6, 2009.

MARTINEZ, G.J.; BARBOZA, G.E. Natural pharmacopoeia used in traditional Toba medicine for the treatment of parasitosis and skin disorders (Central Chaco, Argentina). Journal of Ethnopharmacology, v.132, p.86-100, 2010.

MASABA, S.C. The antimalarial activity of Vernonia amygdalina Del (Compositae). Transactions of the Royal Society of Tropical Medicine and Hygiene, v.94, p.694-5, 2000.

MASELLA, R.T. et al. Novel mechanisms of natural antioxidant compounds in biological systems: involvement of glutathione and glutathione-related enzymes. The Journal of Nutritional Biochemistry, v.16, p.577-86, 2005.

MATHEW, S.; ABRAHAM, T.E. Studies on the antioxidant activities of cinnamon (Cinnamomum verum) bark extracts, through various in vitro models. Food Chemistry, v. 94, p. 520-528, 2006.

MEIR, S. et al. Determination and involvement of aqueous reducing compounds in oxidative defense systems of various senescing leaves. Journal of Agricultural and Food Chemistry, v.43, p.1813-9, 1995.

MELLO, J.P. et al. A dimeric proanthocyanidin from Stryphnodendron adstringens. Phytochemistry, v.51, n.3, p.1105-7, 1999.

MELLO, J.P. et al. Flavan-3-ols and rodelphinidins from Stryphnodendron adstringens. Phytochemistry, v.47, n.3, p.807-13, 1996a.

MELLO, J.P. et al. Prorobinetidinas from Stryphnodendron adstringens. Phytochemistry, v.47, n.3, p.857-62, 1996b.

MESQUITA, M.L. et al. Cytotoxic activity of Brazilian Cerrado plants used in traditional medicine against cancer cell lines. Journal of Ethnopharmacology, v.123, p.439-45, 2009.
MICHALSKA, A. et al. Effect of bread making on formation of Maillard reaction products contributing to the overall antioxidant activity of rye bread. Journal of Cereal Science, v.48, p.123-32, 2008.

MYERS, N. et al. Biodiversity hotspots for conservation priorities. Nature, v.403, p.853-8, 2000.

$\mathrm{NOHL}, \mathrm{H}$. et al. Intracellular generation of reactive oxygen species by mitochondria. Biochemical Pharmacology, v.69, p.719-23, 2005.

ORSI, P.R. et al. Hymenaea stigonocarpa Mart. Ex Hayne: A Brazilian medicinal plant with gastric and duodenal anti-ulcer and anti diarrheal effects in experimental rodent models. Journal of Ethnopharmacology, v.143, p.81-90, 2012.

OYAIZU, M. Antioxidative activity of browning products of glucosamine fractionated by organic solvent and thin-layer chromatography. Nippon ShoKuhin Kogyo Gakkaishi, v.44, n.6, p.307-15, 1986.

PANIZZA, S. Plantas que curam: cheiro de mato. 28 ed. São Paulo: IBRASA, 1997.

PAVAN, F.R. In vitro anti-Mycobacterium tuberculosis activity of some Brazilian "Cerrado" plants. Revista Brasileira de Farmacognosia, v.19, p.204-06, 2009.

PRIETO, P. et al. Spectrophotometric quantitation of antioxidant capacity through the formation of a phosphomolybdenum complex: specific application to the determination of vitamin E. Analytical Biochemistry, v.269, p.337-41, 1999.

PSALTOPOULOU, T. et al. Dietary antioxidant capacity is inversely associated with diabetes biomarkers: The ATTICA study. Nutrition, Metabolism and Cardiovascular Diseases, v.21, p.561-7, 2011.

REBECCA, M.A. et al. Effect of Stryphnodendron adstringens (barbatimão) on energy metabolismin the rat liver. Toxicology Letters, v.143, p.55-63, 2003.

RICE-EVANS, C.A. et al. Structure antioxidant activity relationships of flavonoids and phenolic acids. Free Radical Biology and Medicine, v.20, p.933-56, 1996.

RIZZINI, C.T. Tratado de Fitogeografia do Brasil: Aspectos ecológicos, sociológicos e florísticos. 2.ed. São Paulo: Âmbito Cultural Edições Ltda, 1997, 747p.

RODRIGUES, V.E.G.; CARVALHO D.A. Levantamento etnobotânico de plantas medicinais no domínio do cerrado na região do Alto Rio Grande - Minas Gerais. Ciência e Agrotecnologia, v. 25, p.102-123, 2001

SILVA, J.P. Antinociceptive activity of aqueous extract of Bowdichia virgilioides in mice. Journal of Medicinal Food, v.13, p. 348-51, 2010.

SOARES, J.R. et al. Antioxidant activity of some extracts of Thymus zygis. Free Radical Research Communications, v.26, p.469-78, 1997.

STORZ, P. Reactive oxygen species in tumor progression. Frontiers in Bioscience, v.10, p.1881-96, 2005.

SUO, M.R. et al. Two new compounds from the stem of Vernonia cumingiana. Chinese Chemical Letters, v.19, p.180-2, 2008.

THOMAZZIA, S.M. et al. Antinociceptive and antiinflammatory activities of Bowdichia virgilioides (sucupira). Journal of Ethnopharmacology, v. 127, p. 451-56, 2010.

TIAN, G. et al. Separation of flavonoids from the seeds of Vernonia anthelmintica Willd by high-speed countercurrent chromatography. Journal of Chromatography

Rev. Bras. PI. Med., Campinas, v.15, n.4, p.520-528, 2013. 
A, v.1049, n.1-2, n.219-22, 2004.

TRETIN, D.S. et al. Potential of medicinal plants from the Brazilian semi-arid region (Caatinga) against Staphylococcus epidermidis planktonic and biofilm lifestyles. Journal of Ethnopharmacology, v.137, p.
327-35, 2011.

YESILADA, E. et al. Isolation and characterization of free radical scavenging flavonoid glycosides from the flowers of Spartium junceum by activity-guided fractionation. Journal of Ethnopharmacology, v.73, p.471-8, 2000. 